\title{
Necessity of Modern Textile Spinning Machinaries for Enhancing Productivity Rate
}

\author{
G. Vinothini, R. Priya, S. Jayanthy
}

\begin{abstract}
In this wide society women are facing huge problem. And their role played in the society is also more. As their contribution to their family increased, earning number of women also increased, this made them to play a dual role in the society as a home maker and as employees. This cause stress and also affects their physical and mental health. Working world society and everyday life have changed in the past 50 years almost beyond recognition. Such shifts led to a significant increase in pressure. Stress is induced by both outside and inside the company and by entities that are affected by workers and by employees themselves. Stressors are called the agents or demands that elicit the possible response. Syele says that a stressor "Whatever produces stress with or without functioning hormonal or nervous systems". Among the women employees working in the textile industry, Karur, the present study was carried out. For the study, both primary and secondary data were collected. Using a standardized questionnaire, primary data was collected; copies of the questionnaire were provided by hand to respondents. And secondary data was collected through journals, articles, books and newspaper etc., Due to time constrain, only 100 samples was collected to interpret the result. As the study was not particular about one company, as it is open research convenient sampling technique was adapted for this research. This study enumerates the problem faced by women employees working in textile industry. And it highlighted the factors caused stress to them.
\end{abstract}

Keywords: Ambiguity, Depression, Performance, Resistance, Stress.

\section{INTRODUCTION}

One more description of Stress by Udai Pareek says, "Stress is the term used to denote a stimulus (or cause); the response (physiological, behavioural, or cognitive changes); or the resultant state of the organism[1]-[3]." Work-related stress is defined as a harmful reaction that people have to put undue pressure and work-related demands on them. Stress is difficult to measure by its very nature and has two different sources of data from which to carry out analysis. One of the keys to a happy and successful life in modern society is the stress management process. Existing and performing pressure treadmill in contemporary society is quick to dislodge the inner peace needed for optimal physical and mental health and ability to be at our highest level of

Revised Manuscript Received on December 11, 2019

G. Vinothini, Department of Science and Humanities, Bharath Institute of Higher Education and Research, Chennai , India. Email: gvinothinibcom@gmail.com

R. Priya, Department of Science and Humanities, Bharath Institute of Higher Education and Research, Chennai , India. Email: rathi_priya83@yahoo.com

S. Jayanthy, Department of Science and Humanities, Bharath Institute of Higher Education and Research, Chennai , India. Email: Sjayanthy0903@gmail.com productivity and happiness[4]-[6]. It's time to recognize that our effortful, nervous approach to life based on performance systematically undermines our ability. This study deals with the women employees in the textile sector. Stress plays a tedious role in every person's life[7]. It entered in various ways in family, in workplace, while traveling, from the stranger so on. We cannot avoid those situations or those happenings but it is possible to overcome it before or after it arrive[8].

\section{OBJECTIVES}

- To analysis the problem faced by working women in the work environment

- To identify factor influencing stress.

- To view both the external and internal cause of stress.

- To suggest the remedial measures to avoid job stress.

\section{A. Scope of the Study}

The study entitled with on the problems faced by working women[9]-[14]. The main reason for analysing the working women's problem is to understand their difficulties at work place with the personal / managerial activities. This study inculcated the stress affecting factors both internally and externally. And it gives remedial measures to avoid stress. It also suggests the organization to give solution for avoiding stress for their employees.

\section{REVIEW OF LITERATURE}

When we feel that everything seems to have become too much, we generally use the word "stress"-we are overloaded and wonder if we can really cope with the pressures placed on us.

An agent or stimulus that induces stress is the difference between "stress" and "a stressor." Stress is the feeling that we have when under pressure, while stressors are the things that we react to in our environment. Examples of stressors are noises, unpleasant people, a fast-paced car, or even a first date out. The more stressful we experience, the more stressful we feel in general (but not always).

Stress is a burst of energy, according to experts, which basically advises you on what to do. Stress has many benefits in small doses. Stress will help you meet your daily challenges, for example, and inspire you to achieve your goals. Stress can actually help you perform tasks more effectively. It can enhance memory as well[15]-[18].

Through her thesis, Prof. P. Deepa Ananda Priya studied 


\section{Necessity of Modern Textile Spinning Machinaries for Enhancing Productivity Rate}

Women's Job Stress in IT and ITES Industries, Tamilnadu. She found the effect of demographic variables on job stress in her research and study the influence of job stress on employees ' physical, emotional well-being and turnover plan. The results show that Meeting deadlines and job insecurity are the effect of demographic variables on job stress and job stress on the intention of turnover. The female employees experience more psychological stress than the physiological stress due to job stress. The recommendations were made on the basis of the results.

In his study of work and family, Maryam Zarra-Nezhad, University of Jyväskylä, are the two most important aspects of women's lives. For many communities, work and family responsibilities juggling has become a key personal and family problem. There are many aspects that are subject to pressure in working mother's lives. On a daily basis, we struggle with home and family problems as well as work stress. Due to a number of factors, there is an imbalance between work and family life. Various factors seem to reinforce the brunt of women's pressure. The question was raised as to whether there is a relationship between working women's stress and family difficulties in Iran. Research on working women is greatly needed, particularly with regard to the effect and incidence of work stress on mental health of children[19]-21].

\section{RESEARCH METHODOLOGY}

To satisfy any undertaking, it is important to pursue a precise technique. Research strategy is the primary part of research considers. The procedure pursue by research is itemized here[22].

\section{RESULT AND DISCUSSION}

- Employees feel complicated to share their personal activities

- Stress related problems cannot be identified immediately

- It was not possible to cover all employees in a limited period of time[23]-[24].

- The study totally depends on respondent's views which may be biased in nature.

- The study has been targeted towards sample size of 100.

\section{CONCLUSION}

Working women have become more vulnerable to intense exploitation in the age of globalization; they are exposed to rising threats and are forced to endure more and more physical and mental strain and anxiety. It is not possible to avoid all pressure, and preventing a problem that needs to be addressed is not safe[25]. Nonetheless, you may be surprised by the number of stressors you may remove in your life. In particular, workers should avoid people who annoy them, take control of the situation and focus on the positive in order to avoid stress. The overall study shows that stress factors influences the organization performance because every employee is affected by stress. The stress can be classified in two types "positive stress and negative stress". Positive stress makes person to defend their action in case of sudden reflex. Negative stress comes with the more impact than the positive stress because of environmental factor is the core of the stressors. Stressors i.e. stress stimulus like family, relationship, not satisfied in job, feel depress while working...etc. As the private sector now a day, extracting work form the employees in turn giving less remuneration with less benefits. The women employees working in textile sector suffering with less welfare facilities. And even with night shift by which they feel difficult to look over their family. The organization have to provide welfare facilities which cause stress and also the employees can provide with relaxation program monthly once to reduce the stress and get refreshed both mentally and physically.

\section{REFERENCES}

1) Vasanthi, S. \& Rabiyathul Basariya, S. 2019, "Influence of value analysis and cross training in industry", International Journal of Engineering and Advanced Technology, vol. 8, no. 6, pp. 1810-1811.

2) Velvizhi, R., Sri Gowtham, S. \& Jeya Priya, D. 2019, "Examination of early feedbacks for effective product retailing on E-commerce websites", International Journal of Engineering and Advanced Technology, vol. 8, no. 6 Special Issue 2, pp. 703-706.

3) Anuradha, C., Pothumani, S. \& Kavitha, R. 2019, "A novel method towards E-commerce", International Journal of Engineering and Advanced Technology, vol. 8, no. 6 Special Issue 2, pp. 535-538.

4) Thomas, J. \& Rabiyathul Basariya, S. 2019, "A study on the issues of financial ratio analysis", Indian Journal of Public Health Research and Development, vol. 10, no. 3, pp. 1079-1081.

5) Ramachandran, S. \& Rabiyathul Basariya, S. 2019, "Online marketing study on customer satisfaction and relationship", Indian Journal of Public Health Research and Development, vol. 10, no. 3, pp. 1072-1078.

6) Priya, R., Vinothini, G. \& Cor Jesu, C.D. 2019, "The mentor-protégé relationship for professional growth", Journal of Advanced Research in Dynamical and Control Systems, vol. 11, no. 9 Special Issue, pp. 1110-1119.

7) Jannifer Rani, N., Bina Pani, S. \& Nimisha, N.S. 2019, "A study on money back polices available in LIC", Journal of Advanced Research in Dynamical and Control Systems, vol. 11, no. 9 Special Issue, pp. 833-839.

8) Saillaja, V., Jhansi Rani, K. \& Catherine, R. 2019, "Global marketing management planning and organization", Journal of Advanced Research in Dynamical and Control Systems, vol. 11, no. 9 Special Issue, pp. 489-493.

9) Saillaja, V., Jhansi Rani, K. \& Catherine, R. 2019, "The new phase of marketing information system", Journal of Advanced Research in Dynamical and Control Systems, vol. 11, no. 9 Special Issue, pp. 482-488.

10) Thoufiqulla \& Raju, D.V. 2019, "Perception of indian investor towards investment in mutual funds with special reference to mip funds", Journal of Advanced Research in Dynamical and Control Systems, vol. 11, no. 5, pp. 177-183.

11) Jasmine, K.R.M. \& Basariya, S.R. 2018, "A study on the customers benefits on mutual funds", International Journal of Civil Engineering and Technology, vol. 9, no. 4, pp. 45-48

12) Vasanthi, S. \& Basariya, S.R. 2019, "Pros and cons of on the job training versus off the job training", International Journal of Scientific and Technology Research, vol. 8, no. 10, pp. 671-674.

13) Pavithra, J. \& Ganesan, M. 2016, "A study on awareness and impact of micro-financial schemes", International Journal of Applied Business and Economic Research, vol. 14, no. 8, pp. 5449-5460.

14) Pavithra, J., Dilli Babu, P. \& Ambuli, T.V. 2014, "A study on budgetary control at Maruti Service Masters, Chennai", International Journal of Applied Business and Economic Research, vol. 12, no. 2, pp. 151-161.

15) Gunaraja, T.M. \& Venkatrama Raju, D. 2018, "Determining factors of organisational climate with reference to leadership styles", International Journal of Mechanical Engineering and Technology, vol. 9, no. 9, pp. 1327-1332.

16) Gunaraja, T.M. \& Venkatrama Raju, D. 2018, "The role of job satisfaction and training of employees in determining organisational climate of a selected industry", International Journal of Civil Engineering and Technology, vol. 9, no. 8, pp. 1266-1269.

17) Aarathy, T.S. \& Raju, D.V. 2018, "Performance appraisal and its effects on employees with respect to it sector in Chennai city", International Journal of Civil Engineering and Technology, vol. 9, no. 6, pp. 1535-1538.
Engineering \& Sciences Publication 
18) Aarathy, T.S. \& Raju, D.V. 2018, "Employee perception towards performance appraisal system in IT sector", International Journal of Mechanical Engineering and Technology, vol. 9, no. 5, pp. 131-135.

19) Porselvi, W., Jublee, D. \& Sivanesan, G. 2018, "A study on factors influencing adoption of technology and innovation in banking industry, tamilnadu, India", International Journal of Mechanical Engineering and Technology, vol. 9, no. 5, pp. 789-800.

20) Akessa, G.M. and Dhufera, A.G., 2015. Factors That Influences Students Academic Performance: A Case of Rift Valley University, Jimma, Ethiopia. Journal of Education and Practice, 6(22), pp.55-63.

21) Miller, G. and Shih, C.C., 1999. A faculty assessment of the academic rigor of on-and off-campus courses in agriculture. Journal of Agricultural Education, 40, pp.57-65.

22) Tsinidou, M., Gerogiannis, V. and Fitsilis, P., 2010. Evaluation of the factors that determine quality in higher education: an empirical study. Quality Assurance in education, 18(3), pp.227-244.

23) Farooq, M.S., Chaudhry, A.H., Shafiq, M. and Berhanu, G., 2011. Factors affecting students' quality of academic performance: a case of secondary school level. Journal of quality and technology management, 7(2), pp.1-14.

24) Fitsilis, P., Gerogiannis, V. and Anthopoulos, L., 2014. Ontologies for software project management: a review. Journal of Software Engineering and Applications, 7(13), p.1096.

25) Adams, J.D. and Jaffe, A.B., 1996. Bounding the effects of R\&D: an investigation using matched establishment-firm data(No. w5544). National bureau of economic research.

\section{AUTHORS PROFILE}

G. Vinothini Assistant Professor, Department of Science and Humanities, Bharath Institute of Higher Education and Research, Chennai, India.

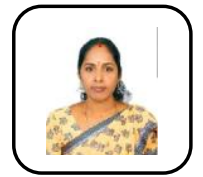

R. Priya Assistant Professor, Department of Science and Humanities, Bharath Institute of Higher Education and Research, Chennai, India.

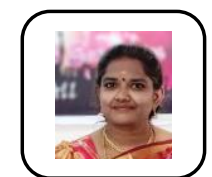

S. Jayanthy Assistant Professor, Department of Science and Humanities, Bharath Institute of Higher Education and Research, Chennai, India. 